\title{
The Ganges shared out
}

BANGLADESH and India have agreed to share the water from the Ganges and to increase the river's flow. The interim agreement lasting five years, which the two countries signed on 5 November, states that they will share the water during the dry months from 1 January to 31 May. Estimates of the amount of water available are based on the recorded flow of the Ganges at Farakka from 1948 to 1973 . The water will be released to Bangladesh for ten days at a time in three instalments each month from January to May.

The agreement also provides for water sharing during the driest period from 21 April to 30 April. At that time, water sharing between India and Bangladesh will be at the rate of 20,500 cubic feet per second and 34,500 cubic feet per second respectively. The total flow at Farakka during the period averages 55,000 cubic feet per second. The actual availability above or below the amount calculated for the period will be shared between the two countries in the same proportion. The signing of the agreement marks the culmination of protracted negotiation between the two countries which has lasted for 25 years and it is thought to be unique between riparian states.

The agreement was signed at about the same time as the Second Committee of the United Nations Environmental Programme (UNEP) constituted an intergovernmental group of experts to draft guidelines for sharing natural resources harmoniously between states. A Bangladesh representative has proposed that a conference on international rivers be organised to evolve and strengthen an institutional framework on a national, regional and international basis to deal with the problems of exploiting and developing international rivers. It is

also suggested that UNEP should be responsible for advising on the development and non-wasteful use of national resources based on sound environmental policy.

The importance of the Ganges to Bangladesh can be judged from the fact that the Ganges delta covers about $37 \%$ of the total area of Bangladesh, and contains about one-third of the total population of the country. The river provides water for drinking and other domestic and industrial uses, sustains agriculture, forestry and fisheries, and facilitates in-land navigation. The increasing demand for greater agricultural output means that water is needed throughout the year. The water available during the dry months may not be enough for the four thousand acres of paddy land dependent on the Ganges.

The task of feeding the fast growing

\section{UK Energy Commission meets}

The DESIRE of Mr Tony Benn, Britain's Secretary of State for Energy, to see a fully-integrated national energy policy came a step nearer to fruition on Monday with the first meeting in London of the newly-established Energy Commission.

The commission is an advisory body set up earlier this year to provide a regular forum for representatives of both the producers and consumers of energy to discuss long-term strategy and specific problems.

Mr Benn, speaking after Monday's meeting, said that he was aware that the Energy Commission did not represent as powerful a set of voices on alternative as on traditional sources of energy-at least as far as research and development was concerned.

"The Government has been criticised by Sir Brian Flowers, as chairman of the Royal Commission on Environmental Pollution, and others for not paying enough attention to alternative sources of energy, and this is a criticism which we accept," he said.

One of the first requests which he had made to Sir Hermann Bondi, recently appointed chief scientist at the Department of Energy, was to look at the balance of research effort and investment between conventional and more novel forms of energy produc- population of Bangladesh from the limited land and water resources is a challenging problem. Cultivating rice, the staple food of the people, is confronted with two serious handicapsthe excess of water during the monsoon and its scarcity throughout the dry months. Controlled irrigation is an alternative but expensive proposition. The Bangladesh Planning Commission, in consultation with the Water Resources Division and the Water Development Board, has proposed four pilot projects, for four different zones of the country, to develop a way of conserving water during the wet season and making it available to the farmers for the rest of the year, particularly during the lean months. The water conservancy programme will also provide a suitable environment for pisciculture and other aquatic sources of food.

M. Kabir

tion.

A great advantage of research in this area was that it was relatively cheap, at least in comparison with the capital intensive investment stages. "It would be sensible for us to expand our support for research over a wide range of possibilities, and then let the development stage bid for part of the energy budget. This is an area in which I am convinced that, given the determination, we can make more efforts more quickly."

The 24-members of the commission include representatives of the energyproducing industries, relevant trade unions, various employers' organisations and consumer bodies. It has been created by $\mathrm{Mr}$ Benn following last year's National Energy Conference, at 